\title{
The Supreme Court, the Law of Nations, and Citations of Foreign Law: The Lessons of History
}

\author{
Daniel A. Farber $\dagger$
}

\section{INTRODUCTION}

The Supreme Court's reliance on "foreign" law has become the subject of heated controversy, particularly with regard to the relevance of foreign authority in constitutional cases. Critics view the Court's citation of foreign legal authority as a threat to the autonomy and integrity of American law, while defenders view the practice as refreshingly cosmopolitan. ${ }^{1}$ This controversy has extended beyond the legal academy and even the legal profession into the public arena, sometimes with startling vehemence.

One flashpoint for the current debate is Justice Kennedy's opinion in Lawrence v. Texas. ${ }^{2}$ In striking down a Texas law criminalizing homosexual conduct, Justice Kennedy found support in European human rights law. ${ }^{3} \mathrm{He}$ emphasized that five years before Bowers (which Lawrence overruled), the European Court of Human Rights (ECHR) considered the

Copyright (C 2007 California Law Review, Inc. California Law Review, Inc. (CLR) is a California nonprofit corporation. CLR and the authors are solely responsible for the content of their publications

$\dagger \quad$ Sho Sato Professor of Law, University of California, Berkeley. Portions of this Article draw on my forthcoming book, Retained BY THE PEOPLE (May 2007).

1. For examples of the neo-isolationist critique of this practice, see, e.g., John O. McGinnis, Foreign to Our Constitution, 100 Nw. U. L. REv. 303 (2006); John Yoo and Robert J. Delahunty, Against Foreign Law (on file with author); Jed Rubenfeld, Unilateralism and Constitutionalism, 79 N.Y.U. L. REv. 1971 (2004); Roger P. Alford, Misusing International Sources to Interpret the Constitution, 98 AM. J. INT'L L. 57 (2004). For an overview of the judicial and scholarly debate about this issue, see Diane Marie Amann, 94 Geo. L.J. 1319, 1324-30 (2006).

2. 539 U.S. 558 (2003). Reliance on foreign law also has deep roots in the Supreme Court's dcath penalty jurisprudence. See, e.g., Thompson v. Oklahoma, 487 U.S. 815, 830 (1988) (finding foreign prohibitions on executions of minors relevant to constitutionality of U.S. practice); Atkins $v$. Virginia, 536 U.S. 304, $316 \mathrm{n} .21$ (2002) ("[W]ithin the world community, the imposition of the death penalty for crimes committed by mentally retarded offenders is overwhelmingly disapproved."); and Roper v. Simmons, 125 S. Ct. 1183,1199 (2005) (relying on international practice in striking down death sentences for offenses committed during thc defendant's minority).

3. Lawrence, 539 U.S. at 573. 
case of a gay man in Northern Ireland, which prohibited same-sex relations. The court held that laws against this conduct violated the European Convention on Human Rights. ${ }^{4}$ The ECHR characterized Irish anti-sodomy legislation as a continuing interference with an individual's right to respect for his private life. Justice Kennedy also found it significant that the ECHR had adhered to its earlier position after Bowers. ${ }^{5}$

Justice Kennedy clearly did not claim that the ECHR's ruling had controlling weight; at most those rulings were one of several bases for his arguments. Nevertheless, Lawrence and other Supreme Court uses of foreign authority set off a political firestorm, replete with congressional condemnations and even calls for impeachments. ${ }^{6}$ This essay will seek a more detached vantage point on the issue, focusing primarily on how the historical record bears on the dispute. As we will see, Justice Kennedy's willingness to refer to foreign judicial decisions in a constitutional setting was far from unprecedented; Chief Justice Marshall would have regarded this practice as uncontroversial. So would have the Framers of the Constitution and of the Fourteenth Amendment.

My purpose in this essay is to examine this controversy in light of historic American attitudes toward the "law of nations" and other forms of foreign authority. ${ }^{7}$ My thesis is that foreign law has deeply permeated our legal system from the very beginning, not only in private law but also in constitutional discourse and adjudication. Citation of foreign law did not merely reflect the paucity of relevant domestic precedent. Rather, it reflected a deeply held understanding of law, in which background legal principles did not derive from any particular jurisdiction. Such background principles percolated through specific Iegal systems, filling gaps and providing context for positive enactments such as statutes and written constitutions. Given this understanding of law, frequent citation of foreign legal authority inevitably resulted from the implementation of transnational legal principles.

The fact that a practice is deeply embedded historically does not prove its validity. It does, however, make it difficult to attack the practice as a suspect modern innovation or to make a plausible claim that disastrous results will surely follow its adoption. It is also difficult to argue that references to foreign sources violate the mandate of the framing generation, when members of that generation assumed that such reference

4. Id.

5. The merits of the Lawrence ruling are beyond the scope of this article. However, 1 believe that the case was rightly decided for reasons discussed in FARBER, supra notc $\dagger$, ch. 14.

6. See Part I infra.

7. Phrasing the topic in terms of "foreign" law is, however, slightly misleading. One of the central points of this essay is that the earlier generations, particularly at the time the original Constitution and the Fourteenth Amendment were framed, did not draw a stark line between U.S. and "foreign" law. Rather, the transnational legal concepts percolated through American law. 
would be made and indeed referred to transnational legal principles in the Constitution itself.

Perhaps some of the sharp reaction to recent opinions such as Lawrence occurred because the issue seemed so novel. Before the recent eruption of debate on the issue, many people were no doubt surprised to learn that the Court has ever relied on anything but home-grown legal sources. As I will show, the practice actually has a long pedigree, but few were aware of this history. Supreme Court use of foreign law was less of a surprise to me. Indeed, my initial exposure to Supreme Court reliance on foreign legal authority had a connection with Paul Mishkin, the distinguished federal courts scholar who is honored in this volume.

My first inkling that foreign law might have relevance to U.S. decisions came when I was a law student, many years before I ever met Paul. Although I was not a student of Paul's in any direct sense, I was deeply influenced by my study of his famous federal courts casebook. I specifically recall one passage in the casebook discussing admiralty law:

What interests are served by making admiralty an area of federal jurisdiction? The original decision to do so was undoubtedly influenced by concern about international relations; consider, e.g., the possible implications of prize cases, involving adjudication of the rights and status of foreign claimants and nations, neutral and belligerence. See The Federalist, No. 80 . The value of uniformity in maritime law was also advanced to support federal jurisdiction. This notion of uniformity reflects the traditional view of the law of the sea as an independent and international body of rules transcending the power of territorial jurisdictions. ${ }^{8}$

This paragraph impressed me, even as a student, with an awareness that American law did not always exist in isolation from the rest of the world. Incidentally, although citations to foreign law may be less frequent today, the Supreme Court continues to endorse admiralty's transnational character. ${ }^{9}$

So far as I know, there have been no passionate attacks on the practice of relying on foreign law in admiralty cases. Constitutional Iaw has a much higher visibility. Constitutional methodology has generally been a controversial subject in recent years, with one of the main disputes being over the primacy of the original understanding versus other interpretative

8. Paul M. Bator, Paul J. Mishkin, David L. Shapiro, \& Herbert Wechsler, Hart and Wechsler's The Federal Courts and the Federal System 904 (2d. ed. 1973) (emphasis added). Perhaps because this was an era when law schools were much less internationally oriented than they are today, this passage made a strong impression on me. More generally, 1 gained from this book much of my sense of what rigorous legal analysis really is.

9. See Norfolk S. Ry. Co. v. Kirby, 543 U.S. 14, 29 (2004) (finding that maritime contracts with an international character should be "judged by one law wherever it was made"); Am. Dredging Co. v. Miller, 510 U.S. 443, 453 (1994)) ("[Admiralty law] is supposed to apply in all the courts of the world.") (quoting Kossick v. U.S. Fruit Co., 365 U.S. 731, 741 (1961)). 
sources. ${ }^{10}$ A full treatment of the issue of reliance on foreign law could take us deep into constitutional theory. But at least it should be possible to iower some of the emotional stakes of the debate simply by providing historical context. An examination of history does not necessarily prove that it is appropriate for the Court to rely on transnational legal sources today-but it does show that doing so has deep roots in the American legal tradition.

Admittedly, the questions of whether, when, and how the Supreme Court should use foreign authority are complex. Even for those who are in the internationalist camp, complicated questions remain about the appropriate occasions for using foreign law, the best ways of assessing that law, and the proper means of determining the implications of foreign law to U.S. constitutional decisions. ${ }^{11}$ My argument addresses only part of this cluster of issues. But history at least provides useful context.

For some readers, rather than merely providing context, this history may be entitled to more substantial weight. History has a more authoritative status for those who adhere to certain jurisprudential provisions-namely, originalists (who favor the understandings of the framing generation) and Burkeans (who favor deference to the slow accretion of historic practice). For readers who find the original understanding or American traditions to be significant or decisive in constitutional interpretation the conclusion should be fairly simple: Strong historical evidence favors reliance on foreign law, when appropriate, in constitutional interpretation as elsewhere.

Part I of this Essay provides additional background on the current controversy. The emotional stridency of the reaction to Lawrence and similar cases has been remarkable. It may rest in part on a misunderstanding of historical practice, though it may also reflect a general suspicion of the judiciary or a broader effort to disentangle the United States from international norms. In any event, critics have not shicd away from voicing their disapproval, sometimes tying their criticisms with threats of impeachment or occasionally of physical violence against the Justices. More sober critics, however, raise substantial arguments that deserve closer examination.

10. For some classic discussions of originalism, see Richard Kay, Adherence to the Original Intentions in Constitutional Adjudication: Three Objections and Responses, 82 Nw. U. L. REV. 226 (1988); Paul Brest, The Misconceived Quest for the Original Understanding, 60 B.U. L. Rev. 204 (1980); Robert H. Bork, Neutral Principles and Some First Amendment Problems, 46 1ND. L.J. 1 (1971).

11. In considering when courts should use foreign authority and how they should do so, a study of practices in different countries may be helpful. As an example of such a comparative study, see Basil Markesinis \& Jorg fedtke, Judicial Recourse to Foreign Law: A New Source of INSPIRATION? (2006). 
Part II turns to the historical record. It explains how "foreign" law-in the guise of the law of nations-influenced the thinking of the Framers of the Constitution and of the anti-slavery Republicans who drafted the Fourteenth Amendment. ${ }^{12}$ The drafters of our key constitutional texts assumed that U.S. law, and in particular the common law, was intertwined with the law of nations. Figures such as Madison and Hamilton took the law of nations, and its relevance to American law, for granted.

Part III then briefly surveys the history of the Supreme Court's use of foreign law in constitutional decisions, which stretches back to the early years of the Republic. Even a sketch of the history eliminates any doubt about the historical pedigree for relying on foreign law. From the early years of the Republic onward, courts have found it appropriate to cite the decisions of foreign tribunals as well as international texts of various kinds. Notably, citation to foreign law in constitutional decisions has been widespread and traces back to John Marshall and before.

Part IV assesses some of the arguments against Supreme Court use of foreign law in light of this history. A full discussion of the arguments is beyond the scope of this essay. Nevertheless, it is important to note the weakness of the case against citing foreign authority once the practice is relieved of the taint of being a recent innovation by liberal activist judges. If, as some contend, the practice is inconsistent with the foundations of American constitutionalism or an impairment of American sovereignty, the Republic seems to have survived these dangers with little sign of strain for the past two centuries.

Finally, Part V considers some of the practical problems facing American judges as they attempt to apply foreign jurisprudence. It may be most useful for our courts to begin by focusing on well-developed Western legal systems, which are likely to be most easily intelligible to our jurists. Jurisdictions with pluralistic, democratic legal traditions are also likely to be the most relevant to understanding constitutional norms such as personal autonomy or equality. Although courts may find it difficult to master foreign jurisprudence, sensible recourse to foreign legal materials is not a forbidding prospect.

My assertion about the weight of the evidence may be controversial, particularly since considerations of time and space preclude full documentation of historical records. There is a narrower conclusion, however, which I do not think can be reasonably disputed. Reliance on transnational legal sources can hardly qualify as a heresy in our constitutional tradition. Rather, it is a deeply rooted and persistent thread in

12. The reason for the use of scare quotes around the word foreign is that the Framers did not necessarily view the law of nations as foreign to U.S. law, but rather as part of the matrix of general law (such as common law) surrounding positive enactments such as constitutional provisions and statutes. 
American constitutional thought. At the very least, those who challenge the action today have a strong burden of proof to overcome.

The Debate over the Court's Use of Foreign LaW

The question of what citations are appropriate in a judicial opinion may seem an arcane technicality, of interest only to students of legal philosophy. On the contrary, however, this question has given rise to a debate that varies from spirited to overwrought. Roughly speaking, conservatives generally have attacked the Court's use of foreign citations while liberals have defended it. Substantive disagreement with the outcomes of the cases may have intensified conservative opposition. The opposition also links with the current conservative attachment to originalism, which deemphasizes the use of any post-enactment sources of meaning, whether American or foreign. Conservative opposition may also be linked with a general endorsement of American unilateralism in foreign affairs.

Whatever the underlying motivation, conservative opposition to citation of foreign law seems to have been a fairly recent development. None other than the late Chief Justice William Rehnquist once endorsed Supreme Court reliance on foreign law as a natural development, though he waffled on the issue later. As Rehnquist explained in a 1993 book chapter, for "nearly a century and a half, courts in the United States exercising the power of judicial review had no precedents to look to save their own, because our courts alone exercised this kind of authority."13 Rehnquist contended, however, that the situation had changed: "now that constitutional law is firmly grounded in so many countries, it is time that the United States courts begin looking to the decisions of other constitutional courts to aid in their own deliberative process." 14 Rehnquist called U.S. courts laggard in this respect, but predicted that "with so many thriving constitutional courts in the world today ... that approach will be changed in the near future." 15 Thus, as of 1993, this doyen of conservative legal thought found nothing alarming about citation of foreign authority. Instead, he seemed to welcome it.

Use of transnational legal authorities also finds support even today among moderate conservatives. In considering the scope of the constitutional prohibition on cruel and unusual punishment in Roper $v$. Simmons, Justices Kennedy and O'Connor both spoke of the significance

13. William Rehnquist, Constitutional Courts-Comparative Remarks, in GERMANY AND ITs Basic Law: Past, Present, and Future 411, 412 (Paul Kirchhof \& Donald P. Kommers eds. 1993).

14. Id.

15. Id. 
of international rulings, ${ }^{16}$ though they disagreed about the proper outcome of that specific case. ${ }^{17}$ Justice Kennedy, writing for the majority, said that the "opinion of the world community, while not controlling our outcome, does provide respected and significant confirmation for our own conclusions." ${ }^{~ 18}$ In dissent, Justice O'Connor explained that America's "evolving understanding of human dignity certainly is neither wholly isolated from, nor inherently at odds with, the values prevailing in other countries." congruence between domestic and international values, especially where the international community has reached clear agreement - expressed in international law or in the domestic law of individual countries - that a particular form of punishment is inconsistent with fundamental human rights. ${ }^{, 20}$ When the Constitution describes certain prohibited punishments as "unusual," after all, it does not expressly limit the universe of comparison to practices of a particular time or place.

The essential division is not so much ideological as philosophical between internationalists and constitutional nationalists, rather than between liberals and conservatives. Often, the division tracks ideological lines, but there is no logical inevitability connecting political attitudes with views of international legal authority.

Justice O'Connor's statement in Roper provides a succinct explanation of the internationalist view of the relationship between U.S. constitutional law and foreign law. Internationalists believe that it is especially important to learn from other constitutional schemes, because many of those constitutional schemes (as well as parts of international human rights law) were modeled on American antecedents. Internationalists find it especially appropriate for the U.S. to be attuned to international human rights law. Human rights law began with the Nuremburg Charter, the United Nations Charters, and the United Nations Organization - all of them initiatives of the United States. ${ }^{21}$ The upshot was the U.N.'s 1948 Universal Declaration of Human Rights, whose premises resemble those of our own Declaration of Independence. Much like the 1776 document, the Universal Declaration proclaims that "all human beings are born free and equal in dignity and rights," and that "everyone has the right to life, liberty, and security of person."22

16. Admittedly, there are undoubtedly some people who consider O'Connor and Kennedy to be arch-liberals, the equivalents of William Brennan and Thurgood Marshall. But this simply reflects a lack of historical perspective.

17. Roper v. Simmons, 541 U.S. 551, 578 (2005).

18. Id.

19. Id. at 605 .

20. Id.

21. See Rubenfeld, supra note 1, at 1981-84.

22. Universal Declaration of Human Rights, G.A. Res. 217A, U.N. GAOR, 3d Sess., 1st Plen. Mtg., U.S. Doc A/810 (Dec. 12, 1948). 
Viewing foreign constitutional and human rights law as sharing the same roots as American constitutionalism, internationalists see no barrier to Supreme Court consideration of these sources of law. As Judge Guido Calabresi has put it, wise parents learn from their children. ${ }^{23}$ Because of the critical role of the United States in establishing these modern international norms, the norms themselves are inherently tied to basic American values of liberty and equality.

Internationalists also view transnational citation as a predictable incident of globalization, particularly given ready access to foreign law electronically. ${ }^{24} \mathrm{As}$ in other fields, international contacts between judges are now much more frequent than in the past. As Justice Kennedy said in an interview on the subject:

It really began with the Holocaust, when international law started to concern itself with how nations treated their own citizens. . . . So you had the beginnings of things like the European Court of Human Rights. They became the new kids on the block, but no one really knew what they did. Gradually, their work started to become known around the world. Then you started to have the formal exchanges of judges.... And then you have informal exchanges, like in Salzburg. You can't help being influenced by what you see and what you hear. ${ }^{25}$

Contrary to internationalists, constitutional nationalists have responded vehemently to the idea of relying on foreign law. The debate went beyond the academy into Congress, where legislators made strenuous efforts to halt this judicial practice. In 2004 and 2005, Senate and House Republicans introduced resolutions banning the use of foreign legal

\footnotetext{
23. United States v. Then, 56 F.3d 464, 469 (2d Cir. 1995) (Calabresi, J., concurring).

24. As Martin Flaherty has said,

Law imitates life overseas as well as at home. The increasing role that the United States plays in the world can only mean a correspondingly greater role for foreign affairs law in the U.S. legal community. As if on cue, the Supreme Court has recently cited international and comparative law materials to a striking, and all but unprecedented, degree. . . Slowly and not entirely surely the U.S. has determined that it cannot avoid becoming an international citizen. The pressures and opportunities of globalization make participation in multilateral regimes such as NAFTA, the 1MF, the WTO, not to mention the U.N. Commission on Human Rights, the U.N. Human Rights Committee, and the United Nations itself harder to avoid.
}

Martin S. Flaherty, The Future and Past of U.S. Foreign Relations Law, 67 L. \& ConTEMP. ProBs 169, 169-170 (2004). The ready availability of foreign law today is remarkable, compared with the need to consult printed volumes that were held only by the best law libraries:

The European Union translates and publishes opinions from nearly fifty nations, and the two most frequently consulted legal databases in the United States, Lexis and Westlaw, carry foreign opinions from dozens of countrics. (The high courts of many countries now also routinely post their opinions on the Internet.) In many American courts, including the Supreme Court, foreign nations and international organizations regularly file briefs citing their own laws.

Jeffrey Toobin, Swing Shift: How Anthony Kennedy's Passion for Foreign Law Could Change the Supreme Court, The New Yorker, Sept. 12, 2005, at 48.

25. Toobin, supra note 24 , at 48. 
authorities. ${ }^{26}$ Representative Sensenbrenner warned that American sovereignty was at risk. ${ }^{27}$ Another Republican congressman bemoaned the use of English authority in particular. After all, Revolutionary War patriots had "spilled their blood.... to sever ties with England forever" - what could be worse than "justice in this land of America" using British court decisions in interpreting our constitution? "What the British could not accomplish by force," he complained, "our Supreme Court has surrendered to them voluntarily." 28 Representative Tom Feeney proposed a bill that would make citation of foreign law an impeachable offense. ${ }^{29}$

Outside of Congress, the public responded even more wildly. One author demanded the impeachment of Justice Kennedy because citing foreign law "upholds Marxist-Leninist, satanic principles."30 Another impeachment call came from the head of a home schooling group. ${ }^{31}$ More disturbingly, an Internet posting called on "commandos" to ensure that two Justices "not live another week" because of their reliance on foreign law. ${ }^{32}$ Of course, due to the Internet, it is easy to locate the lunatic fringe that goes along with any movement; the existence of such a fringe obviously does not discredit the assertions made by more responsible voices. Clearly, however, the Court's practices touched on some deep cultural sensitivities.

A sense that worthwhile legal sources are all "made in America" is certainly not limited to the lunatic fringe who considcr the House of Lords a satanic cult. ${ }^{33}$ On the Supreme Court itself, Justice Thomas refers to "foreign moods, fads, or fashions" when he speaks of non-U.S. law. ${ }^{34}$ Similarly, Justice Scalia sees foreign law as only a fit subject for idle curiosity: "I mean, go ahead and indulge your curiosity! Just don't put it in your opinions!" 35 Similarly, in his confirmation hearings, Chief Justice Roberts said: "Foreign law, you can find anything you want. If you don't find it in the decisions of France or Italy, it's in the decisions of Somalia or

26. Reaffirmation of American Independence Resolution, H.R. Res. 568, 108th Cong. (2004); S.

Res. 92, 109th Cong. (2005).

27. F. James Sensenbrenner, Jr., Remarks, 87 JuDiCa TURE 202, 260 (2005).

28. 151 Cong. Rec. H 3 N5 (daily ed., May 10, 2005)) (remarks of Rep. Poe).

29. H.R. Res. 568, 108th Cong. (2004).

30. See Austin Parrish, Storm in a Teacup: The U.S. Supreme Court's Use of Foreign Law, at 13 n.47 (March 15, 2006), available at http://papers.ssrn.com/sol3/ papers.cfm?abstract_id=891269).

31. Id.

32. See Ruth Bader Ginsburg, A Decent Respect to the Opinions of Humankind: The Value of a Comparative Perspective in Constitutional Adjudication, 1 FLA. INT'L U. L. REv. 27, 33-34 (2006).

33. Some of the resistance seems to be based on a mildly xenophobic disdain for anything foreign, as if only U.S. law can be taken seriously. Perhaps this xenophobia is not too surprising given other indications of national disregard for foreigners. It is remarkable that one chamber of the national legislature has only recently decided that it is okay for its food service to go back to using the term French fries instead of calling them freedom fries. Heaven forbid that our courts should cite any provisions of French law.

34. Foster v. Florida, 537 U.S. 990, 990* (2002) (Thomas, J., concurring).

35. Parrish, supra note 30 , at 56 n. 250 . 
Japan or Indonesia or whatever." ${ }^{36}$ These jurists, then, think that American courts have little or nothing to learn from foreign tribunals.

These somewhat dismissive responses resonate with more elaborate arguments that have been made by some scholars against Supreme Court reliance on foreign authority. Before addressing those arguments directly, however, it is useful to survey the relevant history. The Founding generation, as it turns out, viewed foreign law as something more than a reflection of "moods, fads, or fashions" or a subject for idle curiosity. The views of foreign law currently espoused by the conservative wing of the Supreme Court are far removed from the perspective of the Framers.

II

\section{The Framers and THE LAW OF NATIONS}

It is always difficult to reconstruct the intellectual atmosphere of a bygone era. There are two opposing errors: assuming that past thinkers shared our own basic assumptions, and assuming that whatever we view as new and modern had no counterpart in their era. Earlier generations were both unlike us in unexpected ways and similar to us in surprising respects. In thinking about the use of foreign law, it is easy to fall into both traps at once, reading too many of our assumptions into the past while overlooking how in other respects past thinkers were strikingly similar to ourselves.

On the one hand, a widespread modern assumption is that law is embedded in specific legal systems and derives its force from a sovereign governmental act. Thus, we draw a sharp distinction between foreign law and domestic law - indeed, we learn early in law school to draw this distinction even when thinking about the common law doctrines of various American states. As first year law students learn, the decisions of a state's own supreme court are "binding authority" while those of other courts are merely "persuasive authority." But this vision of law as a product of a particular sovereign is an outgrowth of twentieth-century history, not a universal American stance toward foreign law. Early generations of lawyers did not share the assumption that law was specific to particular territorial sovereigns; they believed that law melded the enactments of particular sovereigns into an internationally shared matrix of general legal norms. If we assume their conception of law was the same as ours, we may slip into anachronism.

On the other hand, we may also make the opposite mistake, overlooking important continuities in thought because we consider past generations to be mired in an archaic and limited worldview. We may tend to assume that internationalism is a new phenomenon, stemming solely from America's engagement in the world in the post-World War II era.

36. Id. at 20 . 
Because a focus on international and comparative law is an emerging trend in law schools today, we may unthinkingly extrapolate backwards into the past and assume that early American legal thinkers were highly parochial. It seems natural enough to assume that the farther back we go, the more parochial and less cosmopolitan the thought of the times. After all, purely as a physical matter, communication and transportation were far more limited in the eighteenth and nineteenth centuries, so we might jump to the conclusion that legal thought was more provincial.

This, too, is a mistake. Legal thinkers in early America were much more cosmopolitan than we might expect. In part because American law was relatively undeveloped, and in part because of their assumptions about universal background rules, American legal and constitutional thinkers from the Revolution to the Civil War were keenly interested in rulings of foreign courts and the views of foreign legal scholars. In legal writings and constitutional debates, they found it natural to appeal to those foreign legal authorities for support.

In particular, it is easy today to underestimate the influence of foreign legal thinkers on Americans-not just English sources such as Blackstone and Coke, but also continental legal writers. Although they have been largely forgotten today, several writers about the law of nations were highly influential in eighteenth- and early nineteenth-century America. ${ }^{37}$ One of these thinkers was Pufendorf. As his major modern commentator says, "Samuel Pufendorf is known to American students-when he is known at all-as an obscure German with a funny name who followed Grotius in the early development of international law."38 Nevertheless, despite having an admittedly funny name, he was a highly influential figure. Pufendorf's natural law system stressed the social nature of human beings and their duty to protect each other's welfare. Like John Locke, he also stressed human equality and the compact theory of government. Pufendorf was no obscure fignre at the time: sixteen editions of his most famous work on natural law were published in England in the decades before the American Revolution. ${ }^{39}$

An even more influential thinker was Emmerich de Vattel. Vattel's work mainly involved international law but contained some important

37. For more extensive discussion of the influence of law of nation and social compact thought on the Framers, see Daniel A. Farber \& Suzanna Sherry, A History of the American CONSTITUTION 11-15, 21, 367-72 (2d ed. 2005). For some examples of citations to these authors by early leading Justices, see Steven G. Calabresi and Stephanie Dotson Zimdahl, The Supreme Court and Foreign Sources of Law: Two Hundred Years of Practice and the Juvenile Death Penalty Decision, 47 WM. \& MARY L. REV. 743, 770-71 (2005).

38. Leonard Kreiger, The Politics of Discretion: Pufendorf and the Acceptance of Natural LaW 1 (1965).

39. R.H. Helmholz, Natural Law and Human Rights in English Law: From Bracton to Blackstone, 3 Ave MARIA L. REv. 1, 3-4 (2005). 
observations on natural law. ${ }^{40} \mathrm{He}$ postulated that society is obliged to preserve its members and cannot override their natural right to selfdefense. If the sovereign violates fundamental rights, the nation as a whole can withdraw its obedience. Vattel's extensive writings on international law have been deeply influential in terms of U.S. law - for example, he has been cited over 150 times by the United States Supreme Court, including as recently as $2004 .^{41}$

Early American lawyers immersed themselves in the work of these thinkers. Consider, for example, this description of Alexander Hamilton by a prominent historian:

The big influences on Hamilton were the economists he read and also the philosophers of natural law and English constitutional law. The philosophers of natural law have sort of dropped off our map of what intellectual history was. We don't read Hugo Grotius anymore. 1 tried for the Hamilton book, but it's really hard. He's a very dense, bad writer. But he was a big figure in his day, as were Jean-Jacques Burlamaqui and Pufendorf. These were on the lists of names that people read, and they were very important to Hamilton. He was a lawyer; that was his profession when he wasn't in the army or in politics. And he liked the law. 1 think he understood it, and he certainly took it very seriously. So, in his legal arguments, he will toss in references to Grotius and to Vatell [sic], in addition to references to Blackstone, to Coke, and the more standard English legal philosophers. 1 think that's where you look for his intellcctual background. ${ }^{42}$

John Adams provides another example of familiarity with Vattel and Pufendorf. Consider the following incident (relating to the dispute over ratification of a new treaty):

To fight that attack, Adams scoured the half-finished city for law books, and he managed to dig up a copy of Emmerich de Vattel's book on The Law of Nations. He easily found what hc wanted from Vattel, but he needed further support, and so he had his son Thomas do the legwork in Philadelphia. "l wish you would look into Grotius \& Puffendorf among the rules for the interpretation of treaties, \& send me extracts of the law upon this point." 43

Today, wc may think of natural law as a moral theory quite sharply distinct from the mundane fabric of ordinary legal rules. But in an earlier era, the two were interpenetrated. Natural law, as exemplified by these

40. Vattel's principal work has been made available on-line in the original French at http://oll.libertyfund .org/Home3/Set.php? recordlD $=0586$.

41. Westlaw search (Oct. 10, 2006).

42. The American Enlightenmont's Other Side, at http://www.objectivistcenter.org/ showcontent.aspx?ct $=150 \& \mathrm{~h}=51$.

43. Richard Samuelson, The Midnight Appointments, The White House Historical Association, http://www.whitehousehistory.org/08/subs/08_b07.html. 
thinkers, was an important part of English common law. The eminent legal historian R.H. Helmholz recently undertook a thorough survey of the impact of natural law on the English common law. ${ }^{44}$ He has compiled a list of over sixty leading English legal writers who endorsed natural law as part of the common law before the American Revolution. The list included many of the great names of English legal history such as Lord Coke, Lord Mansfield, Sir Thomas Littleton, and Matthew Hale - not to mention one bona fide saint (Thomas More). ${ }^{45}$

These thinkers, Helmholz concluded, saw natural law as a legitimate source of English law, not an exotic foreign import. He also observed that the idea of natural law surfaced in some of the common law's most famous cases. ${ }^{46}$ For instance, a case from 1468 referred to the law of nature as "the ground of all laws" and described it as the basis for decision when precedents were lacking. ${ }^{47}$ English lawyers did not draw any sharp distinction between the common law and natural law, for they assumed that reason and natural law "stood behind and supported the English common law." S8 Similarly, as historian Jack Rakove explains, colonists did not "regard English rights as a weak alternative to the great natural rights of mankind; English rights were the legal application of natural rights." 49

As their knowledge of writers like Vattel and Pufendorf indicated, the Framers had a global intellectual vision. The fact that the Supreme Court looks beyond our own borders shocks many of today's conservatives. The Founding Fathers and their successors were far more cosmopolitan. As the examples of Adams and Hamilton show, references to writers like Vattel and Pufendorf were second-nature to them. This is hardly surprising, since there was a dearth of American precedents to provide guidance.

Certainly, the Framers had no qualms about looking to foreign and international law. They frequently took guidance from what they called the "law of nations." The law of nations has no exact counterpart today. It was a blend of legal fields we would now consider quite distinct, including

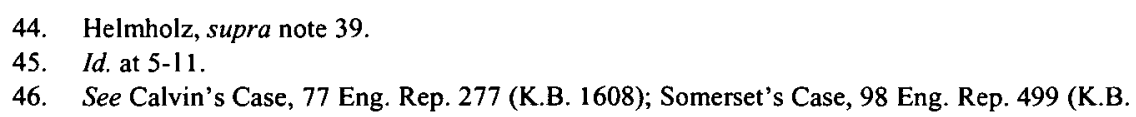
1772); Moses v. Macferlan, 97 Eng. Rep. 676 (K.B. 1670) (cited in Helmholz, supra note 39, at 20).

47. See Helmholz, supra note 39, at $20 \mathrm{n} .124$ ("ley de nature que est le ground de touts leys").

48. Id. at 21. As Helmholz explains

[C]loser examination shows considerable variation in how much attention these English lawyers devoted to natural law. Some of them mentioned it in a quite superficial way ... Others, however, went farther into the available learning ... Christopher S. German is an example. Natural law served as a frequent starting point for his analysis of English law. Still others endorsed it and went on to provide examples of how its precepts were expressed in rules and maxims of the common law. Sir John Doderidge is an example.

Id. at 11-12.

49. Jack N. Rakove, Original Meanings: Politics and Ideas in the Making of the Constitution 293 (1996). As Helmholz points out, natural law played an important role in statutory interpretation. Helmholz, supra note 39, at 17. 
natural law, public international law and commercial law. These fields were part of the lawyer's toolkit. As Dean Alex Aleinikoff observes, "Early U.S. jurists were schooled on the leading international treatises, the lex mercatoria, the law of prizes, Roman Citizenship law, and British constitutionalism."50

According to one influential nineteenth-century American judge and legal commentator, the law of nations derived from "principles of right reason, the same views of the nature and constitution of man, and the same sanction of Divine revelation, as those from which the science of morality is deduced." A key element of the law of nations was the "general principles of right and justice, equally suitable to the government of individuals in a state of natural equality, and to the relations and conduct of nations." 52

The idea of an unwritten transnational law tracked the thinking of the legal community in the nineteenth century. Today, we think of the common law as specific to each individual state or country. But until the twentieth century, the common law was considered to be separate entity, shared by all common law courts, rather than a mere aspect of a specific state's law. In the early nineteenth century case of Swift v. Tyson, ${ }^{53}$ the Supreme Court held that federal courts would apply the "general common law" rather than the rulings of any particular state court in resolving disputes. In setting down this rule, the Court drew a phrase from Roman law to the effect that certain rules are "not just the law of Rome or Athens or any one place, but the law of all people at all times." 54 Today, the Court has repudiated that view of the common law. But to early Americans, the opposite view came very easily. ${ }^{55}$ For them, the common law was not merely a quasi-legislative act by the courts of a particular jurisdiction, but an effort to recognize and apply universal principles.

Another indication of the significance of the law of nations comes from the Constitution itself. Article I of the Constitution empowers Congress to define and punish "Offences against the Law of Nations." Accordingly, the very first Congress passed the Alien Torts Statute, which

50. Alexander Aleinkioff, Thinking Outside the Sovereignty Box: Transnational Law and the U.S. Constitution, 82 TeX. L. REv. 1989, 1989 (2004).

51. James Kent, 1 Commentaries on AMERICAN LAW *2 (1896).

52. Id. at $* 3$.

53. 41 U.S. (16 Pet.) 1 (1842),

54. Id. at 19 ("Non erit alia lex Romae, alia Athenis; alia nunc, alia posthac; sed et apud omnes gentes, et omni tempore una eademque lex obtinebit.").

55. A particularly striking case was Watson v. Tarpley, 59 U.S. (18 How.) 517 (1855), a diversity case involving a negotiable instrument. Although the case had been brought in Mississippi by a Mississippi citizen, the Court refused to apply the relevant Mississippi statute. The Court's theory was that the general commercial law could not be deprived of its force in federal court by a mere state statute.

56. U.S. CONST. art. $1, \S 8$. 
grants the federal courts jurisdiction over any civil action by an alien for a tort "committed in violation of the law of nations or a treaty of the United States." 57

This statute has given rise to recent Supreme Court discussion of the Framing generation's conception of the law of nations. As the Court has explained, in passing the statute the first Congress anticipated that the courts would recognize private causes of action for certain torts in violation of the law of nations. ${ }^{58}$ According to the Court, Congress clearly assumed that federal courts could enforce international norms. ${ }^{59}$ Notably, the Court also remarked that this understanding remained effective even today, notwithstanding the modern shift in views about the status of the common law. It would be unreasonable, the Court observed, to assume that courts would "lose all capacity to recognize enforceable international norms simply because the common law might lose some metaphysical cachet on the road to modern realism.",60

The Court's observation bears some influence. Our picture of law may not be the same as the Framers. For example, we may think of the common law as gaining its legal force from the rulings of courts within a specific jurisdiction rather than from its status as a set of trans-jurisdictional legal principles. But this does not keep us from recognizing that courts in many jurisdictions confront similar problems, consider carefully each others' answers, and seek to create a coherent body of law. It is for this reason that enterprises like the American Law Institute's Restatements of the common law have been so influential, although they lack any kind of binding legal force. Similarly, as the Supreme Court recognized, widely recognized international norms are given effect within the American legal system in a variety of ways, such as the Alien Tort Claims Act. Thus, although the metaphysics of the Framers' view of law is no longer ours, the modern legal system can also recognize and implement transnational legal norms at an operational level. The terminology and philosophical underpinnings of the law of nations may have shifted, but the legal system still embodies its essential features.

These aspects of modern law are quite consistent with the worldview of the Framers. Looking beyond their own borders came naturally for the Framers. According to the Declaration of Independence itself, the motivation for issuing this foundational document stemmed from a "decent Respect to the Opinions of Mankind."61 Early Americans, from Thomas Jefferson on down, understood that the law of nations composed part of

57. Originally included in The Judiciary Act of 1789 , the Alien Tort Statute is now codified as 28 U.S.C. $\S 1350$ (1948).

58. Sosa v. Alvarcz-Machain, 542 U.S. 692, 731 (2004).

59. Id. at 694 .

60. Id. at 731 .

61. U.S. Declaration of Independence, para. 1 (U.S. 1776). 
American law. ${ }^{62}$ For example, an early attorney general argued that it was "essentially a part of the law of the land." 63 Alexander Hamilton argued that the law of nations made up part of the common law. ${ }^{64}$

Early opinions of the Supreme Court also reflected this broad acceptance of the law of nations. 1 will consider the Court's historic pattern of citation to foreign authority in detail in Part III. For present purposes, the key point is not which sources the Court cited in its opinions, but rather the more jurisprudential point that the Court viewed domestic and international law as deeply intertwined.

Chief Justice Marshall proclaimed in The Charming Betsy ${ }^{65}$ that federal laws "ought never to be construed to violate the law of nations if any other possible construction remains." Marshall also made it clear that, in the absence of legislation, the Supreme Court was "bound by the law of nations which is a part of the law of the land." said, "the early Supreme Court saw the judicial branch as a central channel for making international law part of U.S. law."67 "Like it or not," he adds, "both foreign and international law are already part of our law." 68 This principle also receives recognition today. In The Paquete Habana, ${ }^{69}$ which remains influential today, the Court said that:

International law is part of our law, and must be ascertained and administered by the courts of justice of appropriate jurisdiction... For this reason, where there is no treaty, and no controlling executive or legislative act or judicial decision, resort must be had to the customs and usages of civilized nations; and, as evidence of these, to the works of jurists and commentators, who by years of labor, research and experience, have made themselves peculiarly well acquainted with the subjects of which they treat. ${ }^{70}$

Awareness of the law of nations did not cease with the ratification of the Constitution. It also influenced the anti-slavery Republicans who drafted the Reconstruction Amendments. Based on the statements of the Framers, the constitutional debates, and the Federalist Papers, Senator Seward stated the basic Republican position that the Constitution did not

62. On Jefferson's views, see Charles M. Wiltse, Thomas Jefferson on the Law of Nation, 29 AM. J. INT'L L. 66 (1935). Note Jefferson's reliance on Grotius, Pufendorf, and especially Vattel. Id. at $68-69,75$.

63. 1 Op. Att'y Gen. 26, 27 (1792).

64. William Michael Treanor, Judicial Review Before Marbury, 58 STAN. L. REv. 455, 480-81 (2005).

65. Murray v. The Schooner Charming Betsy, 6 U.S. (2 Cranch) 64, 118 (1804).

66. The Ncreide, 13 U.S. (9 Cranch) 388, 423 (1815).

67. Harold Koh, International Law as Part of Our Law, 98 AM. J. INT'L L. 43, 44 (2004).

68. Id. at 57. See also Emest A. Young, Sorting Out the Debate Over Customary International Law, 42 VA. J. INT'L L. 365, 467 (2002) (Customary international law "should be viewed as 'general' law, just as it was in the nineteenth century.").

69. I75 U.S. 677 (1900).

70. Id. at 700 . 
endorse slavery but left that question to the law of nature and of nations. "That law, as expounded by Vattel, is founded in the reason of things."71 According to most pre-Civil War Republicans, the law of nations provided a default rule against slavery, which could only be overcome by explicit legislative enactment. ${ }^{72}$ For this reason, a slave who entered free territory automatically became free, except to the extent the Fugitive Slave Clause (as an explicit positive enactment) required otherwise. Also, under the law of nations, slavery was illegal in the territories in the absence of express congressional authorization. ${ }^{73}$ Thus, the law of nations provided a set of default rules that legislatures could overcome by specific enactments in a particular jurisdiction, but which continued to have legal force as a matter of domestic law in the absence of such an enactment.

One particularly widespread concept among Republicans, drawn from the law of nations but applied to constitutional law, was the reciprocity between citizenship and government protection. As one member of the Reconstruction Congress put it, "there are characteristics of Governments that belong to them as such... The rights and duties of allegiance and protection are corresponding rights and duties."74 The right of a citizen to protection under the law of nations was frequently cited as providing a constitutional basis for the Civil Rights Act of 1866. For example, Representative Wilson argued that the Civil Rights Act rested upon the power of any government to protect its citizens and that "the right to exercise this power depend upon no express delegation, but runs with the rights it is designed to protect." 75 Thus, the law of nations helped to determine the constitutional authority of the federal government.

For the Framers, it was not generally critical to distinguish between different sources of law, whether those sources were common law decisions, international law, or moral principles. The legal thought of an earlier era certainly recognized distinctions between morality and law, as exemplified by Chief Justice Marshall's unhappy admission that the slave trade, while certainly a violation of natural law, did not violate international law because international practice accepted it. ${ }^{76}$ Nevertheless, the kind of stark compartmentalism that seems natural to many people today did not characterize earlier thought. Admittedly, positive law, whether in the form of specific enactments or international practice, could

71. Cong. Globe, 31 st Cong., 1st Sess., App. 264 (1850).

72. This viewed derived from Lord Mansfield's holding that the "state of nature is of such a nature, that it is incapable of being introduced on any reasons ... but only positive law ... It's so odious, that nothing can be suffered to support it, but positive law." Sommerset v. Stewart, 98 Eng. Rep. 499, 510 (K.B. 1772).

73. Farber \& Sherry, supra note 37 , at $371-72$.

74. Cong. Globe, 39th Cong., 1st Sess. 1263 (remarks of Rep. Broomall). For other statements by Republicans to the same effect, see Farber \& Sherry, supra note 37, at 430-33.

75. Cong. Globe, 39 th Cong. 1 st Sess. $1119(1866)$.

76. See The Antelope, 23 U.S. (10 Wheat.) 66 (1826). 
override background moral norms. But more often, positive enactments, judicial rulings from various jurisdictions, and moral norms seemed to blur together as sources of legal rules.

An analogy might be seen in the way that courts today read specific contractual terms in the context of trade usages. ${ }^{77}$ Trade usage and judicial determinations of reasonableness can also fill gaps in contract terms. ${ }^{78}$ Express contractual language can escape from these background norms, but such readings are not favored. Thus, a trade usage can provide an enforceable source of obligations on the parties to a contract where the contract language is silent or provide a strong argument for interpreting contract language in a particular direction. Similarly, in earlier times, widely shared moral norms as applied by courts and other legal authorities could mold the interpretation of specific enactments and help to fill gaps in those enactments. Just like trade usage or conceptions of commercial reasonableness today, there was no reason to limit these earlier sources of background rules to a single jurisdiction.

The Framers of the Constitution were not isolationists. They were immersed in legal thinking from around the world. In turn, they brought this learning to bear when they confronted constitutional issues. Many of those who otherwise prioritize the original understanding, however, want to build a wall between U.S. constitutional law and the rest of the world. Whatever can be said in favor of this position, it did not correspond to the views of the Framers or, as we will see in Part III, to the historic practice of the Supreme Court.

\section{III}

\section{The American Tradition of Judicial Citation to Foreign Law}

Fortunately, it is not necessary to recount the full history of Supreme Court citations to foreign authority at length: that task has already been undertaken by others. Recently, Steven G. Calabresi and Stephanie Dotson Zimdahl coauthored a 164-page law review article that surveys the Supreme Court's use of foreign authority since $1793 .^{79}$ The length of the

77. See Uniform Commercial Code (U.C.C.) $\S$ I-303; Restatement (Second) of Contracts $\S 222$

78. See U.C.C. \& 1-303(d):

A . . usage of trade in the vocation or trade in which they are engaged or of which they are or should be aware is relevant in ascertaining the meaning of the parties' agreement, may give particular meaning to specific terms of the agreement, and may supplement or qualify the terms of the agreement.

See also Restatement (Second) of Contracts $§ 222(3)$ :

Unless otherwise agreed, a usage of trade in the vocation or trade in which the parties are engaged or a usage of trade of which they know or have reason to know gives meaning to or supplements or qualifies their agreement.

79. Steven G. Calabresi \& Stephanie Dotson Zimdahl, The Supreme Court and Foreign Sources of Law: Two Hundred Years of Practice and the Juvenile Death Penalty Decision, 47 WM. \& MARY L. REv. 743 (2005). 
article by itself may say everything really necessary: there have been many Supreme Court opinions citing foreign authority. Here is what the research found: "those political and journalistic commentators who say that the Court has never before cited or relied upon foreign law are clearly and demonstrably wrong. In fact, the Court has relied on such sources to some extent throughout its history." ${ }^{\circ 0}$ Indeed, early judges felt comfortable enough with foreign sources to quote extensively from Grotius (the great Dutch master of international law) in Latin without providing an English translation. ${ }^{81}$ The "English Only" movement apparently had not yet taken hold.

In particular, the Calabresi and Zimdahl survey showed that in construing the law of nations, the early Supreme Court considered a variety of foreign sources: the laws and practices of other nations, especially those on the European continent; the views of foreign scholars; and rulings by the English courts. One striking early case to use foreign law was Brown $v$. United States, ${ }^{82}$ an outgrowth of the War of 1812 . What makes this case so notable is that the Court used foreign law to help interpret a clause in the U.S. Constitution.

The question in Brown was whether British property automatically forfeited to the U.S. government when war was declared, giving the President the power to seize the property without any further authorizing legislation. Chief Justice Marshall ruled that the answer was no. Marshall said that the Constitution "was framed at a time when this rule... was received throughout the civilized world. In expounding that constitution, a construction ought not lightly to be admitted which would give to a declaration of war an effect in this country it does not possess elsewhere. ${ }^{183}$ Under the law of nations, declaration of war did not result in automatic forfeiture of the property of enemy aliens. Hence, Marshall concluded, the property did not automatically revert to the U.S. government when war was declared, so the President lacked the constitutional power to seize the property without congressional authorization. ${ }^{84}$

Another important use of foreign law came in the dissents from Dred Scott, the Supreme Court's infamous pro-slavery opinion. The dissenters cited English cases as well as European civil law to support their critique of the Court. ${ }^{85}$ One of them concluded that the majority opinion conflicted with "fundamental principles of private international law." Chief Justice Taney took the opposite tack regarding foreign law in his pro-

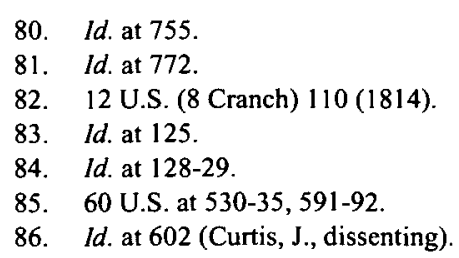


slavery opinion: "No one, we presume, supposes that any change in public opinion or feeling .... in the civilized nations of Europe or in this country, should induce [this Court] to give to the words of the Constitution a more liberal construction.... than they were intended to bear when the instrument was framed and adopted." $" 87$

The Supreme Court also looked to foreign law in one of its early opinions construing the Fourteenth Amendment. In an 1884 case, the issue was whether due process allowed criminal prosecutions to go forward without a grand jury indictment. ${ }^{88}$ The Court looked to foreign law to help answer this question. The Constitution, the Court said, was "made for an undefined and expanding future, and for a people gathered and to be gathered from many nations and many tongues." ${ }^{\circ 9}$ The Court added that "there is nothing in Magna Charta, broadly construed, which ought exclude the best ideas of all systems and of every age." 90 It was, the Court said, "the characteristic principle of the common law to draw its inspiration from every fountain of justice," and "we are not to assume that the sources of its supply have been exhausted." jury indictment was not fundamental and hence not a mandate of the due process clause.

Also in 1884, in upholding the federal government's constitutional power to issue paper money, the Supreme Court relied on foreign law to show that this power was universally viewed as an inherent power of sovereignty. 92 The explicit constitutional grant of power to "coin" money might suggest of the absence of a power to print paper money, but the Court upheld Congress's power to issue paper money based on international practice. Specifically, the Court referred to the common practice of European governments to issue such money, and also cited an English ruling involving the King of Hungary that recognized this power. ${ }^{93}$

$1 t$ is tempting to continue, but one exhaustive survey of the Court's deeisions is enough. The conclusion is clear enough. It is far from novel for the Supreme Court to look abroad when interpreting our Constitution. The evidence for reliance on foreign law is particularly strong in this regard for cases involving the law of nations. Anyone who says otherwise just has not looked at the evidence. If Anthony Kennedy should be condemned for

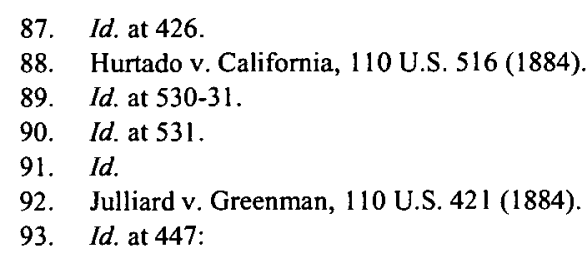

This power has been distinctly recognized in an important modern case, ably argued and fully considered, in which the Emperor of Austria, as King of Hungary, obtained from the English Court of Chancery an injunction against the issue in England, without his license, of notes purporting to be public paper money of Hungary. 
citing foreign law in constitutional cases, so should many of the most illustrious Justices in the Court's history.

\section{IV}

\section{ReEXamining the Debate in the Light of History}

Although some resistance to consulting foreign law may reflect only prejudice, there are also some substantive arguments. A full consideration of these arguments goes beyond the scope of this essay, but it is worth pausing to consider them briefly.

One argument by constitutional nationalists is that using foreign law to interpret "our" Constitution somehow undermines our sovereignty. When we consider the historical use of foreign authority by the Framing generation and numerous Supreme Court Justices since John Marshall, this argument might raise some question about whether the United States actually ever has had full sovereignty. If citing foreign law is incompatible with sovereignty and our courts have engaged in this practice since the beginning, our national claim to sovereignty seems questionable. This historical point merely highlights the weakness of the argument. It certainly seems odd that the principal drafter of the Declaration of Independence was also a staunch believer in the law of nations, if national independence and the law of nations are at odds.

To some extent, the sovereignty argument scems based on a logical error. The assumption seems to be that if the courts consider legal materials from outside their jurisdiction, they are in effect submitting to the authority of those other jurisdictions. It is only that logical error which makes it possible to entertain the possibility that the Marshall Court was a vassal to foreign powers because it relied on foreign legal writings. Something seems seriously amiss about such an argument.

The sovereignty argument misses the mark. State courts around the nation constantly disprove the general proposition - that giving weight to foreign legal decisions amounts to a transfer of sovereignty. State courts cite decisions from other states constantly, especially nearby states. When a Nevada courts cites California law, it obviously is not giving the California courts any jurisdiction over Nevada.

Such cross-state citations are very common in decisions interpreting state constitutions. One study suggests that over one-third of state constitutional decisions refer to out-of-state cases. ${ }^{94}$ In fact, state courts have sometimes specifically suggested that lawyers discuss the relevance of out-of-state rulings. Yet it seems more than a little implausible to assert

94. James N.G. Gauthen, Horizontal Federalism in the New Juridical Federalism: A Preliminary Look at Citations, 66 ALB. L. REv. 783 (2003). 
that using California rulings to interpret the Nevada constitution somehow makes Nevada a colony of California. ${ }^{95}$

The problem with the sovereignty argument is that it confounds the seat of authority-which in the case of the Supreme Court is obviously U.S. federal law-with sources of interpretation. Foreign authority is relevant in constitutional cases only to the extent that it helps clarify the meaning and application of provisions of the United States Constitution. Sometimes the relevance may be factual. For instance, where the validity of a statute depends on whether it is necessary to achieve a compelling governmental interest, it is factually relevant to see whether other jurisdictions have been able to achieve the government interest without using similar measures. Likewise, if the constitutionality of a punishment depends on whether it is unusual, this is in part a factual matter which can be clarified by seeing how common the punishment is in other jurisdictions. On other occasions, the relevance stems from the open-ended nature of a constitutional standard. The Fourth Amendment prohibits unreasonable searches; considering the actual practice of law enforcement agencies in other jurisdictions may be relevant to determining whether a type of search is reasonable. None of these uses of foreign law remotely impairs U.S. sovereignty. The operative constitutional text is American, and the relevant American decision maker, the Supreme Court, makes the final decision as to what materials have interpretative significance.

The underlying logic of the sovereignty argument seems to be something like the following: If foreign decisions are relevant, then they must at least function as tie-breakers, meaning that in some cases they will determine the outcome. Thus, in some cases, acts of foreign governments (in the form of foreign judicial rulings) will control the outcome of the decision; hence, those governments will be exercising power over American law at the expense of American sovereignty. Essentially, this argument views the foreign ruling as the but-for cause of the U.S. legal decision. To be the but-for cause of something is not to exercise power over it, however. To give a command may be the but-for cause of a subordinate's actions, but causation is not enough. (Otherwise, when textualists such as Scalia and Thomas cite a dictionary, they would be delegating part of the judicial power to book publishers - if the dictionary is relevant, at least in some case it must be the but-for cause of a ruling. But obviously this does not mean that the book publishers are exercising authority over the Justices.) Other elements also seem to be necessary: the pcrson issuing the command must intend to direct the subordinate's

95. A related topic of interest is the use of international law to interpret state constitutions. See Martha F. Davis, The Spirit of Our Times: State Constitutions and International Human Rights, 30 N.Y.U. Rev. L. \& Soc. Change 359 (2006). Davis cites some evidence of reference to international norms by drafters of state constitutions. Id. at 372, nn.51-52. 
actions; there must be a reasonably high ex ante probability that the command will be effective; and the subordinate must not have the option of independently determining whether to follow the command. In short, power is not merely a matter of causation in a specific case; it is part of a social relationship between the superior and the subordinate. The United States Supreme Court is not in such a relationship with, for example, the European Court of Human Rights; when our Court chooses to give weight to some ruling of the ECHR, it is not acting as a subordinate. Sovereignty, at least in one sense, means that no outside government agency exercises power on our soil; citation of foreign law does not infringe on that conception of sovereignty.

Another argument made by the Court's critics is that the U.S. Constitution is purely based on our own culture and history. Hence, there is supposedly nothing we can learn about it from outsiders, any more than one can perfect one's English by consulting a French dictionary. From this point of view, the basis of constitutional law is purely a specific nation's history and culture. For example, Justice Scalia says that he does not believe that "approval by 'other nations and peoples' should buttress our commitment to American principles any more than (what should logically follow) disapproval by 'other nations and peoples' should weaken that commitment." 96

The crux of the nationalist argument is that American constitutional guarantees, such as free speech or due process or the ban on slavery, represent distinctively American principles, not universal principles of human rights. There is a deeper issue here about the nature of our own Constitution. A number of critics of foreign law - mostly but not entirely from the Right - argue that foreign constitutionalism finds its basis in a different theory than the one held by Americans. Our Constitution, supposedly, gains all of its strength from the populist act of ratification. Its contents are the dictates of We the People. What makes the Constitution important is that it is the law we have given ourselves. As Jed Rubenfeld puts it, "a constitution is, first and foremost, supposed to be the foundational law a particular policy has given itself through a special act of popular lawmaking." 97 In contrast, foreign constitutions rest on the idea that people have universal human rights, which should be honored apart from any peculiar mandates of local law. ${ }^{98}$

It may well be true that some constitutional rights, such as the right to a jury in a civil case, were tied to specific features of the American legal

96. Roper, $125 \mathrm{~S}$. Ct. at 1229. American exceptionalism is also stressed in John Yoo, Peeking Abroad? The Supreme Court's Use of Foreign Precedents in Constitutional Cases (on file with author).

97. Rubenfeld, supra note 1, at 1975.

98. For a good rebuttal of this argument, see Vicki C. Jackson, Constitutional Comparison: Convergence, Resistance, Engagement, 119 HARv. L. REv. 109, 120-21 (2005). 
system rather than more universal aspirations. The somewhat distinctive phrasing of this guarantee reflects its roots in American legal practice. ${ }^{99}$ But history shows that other guarantees clearly have a much more universalistic foundation.

For example, the supporters of the Thirteenth Amendment believed that slavery was a universal wrong, not just a violation of some peculiarly American norm. After all, the United States was the only major Western society that allowed slavery; owning slaves could almost be said to be as American as apple pie. For this reason, supporters of the Thirteenth Amendment found their support in the universals of the Declaration of Independence. Consider the remarks of Senator Reverdy Johnson who was a particularly cool-headed legal thinker, rarely given to rhetorical flights. (Johnson was also far from being a zealous abolitionist: he had actually represented the slave-owner in the Dred Scott case.) In explaining the justification for the Thirteenth Amendment, Johnson said:

We mean that the Government in the future shall be as it has been in the past, ... an example of human freedom for the light and example of the world, and illustrating in the blessings and the happiness it confers the truth of the principles incorporated into the Declaration of Independence, that life and liberty are man's inalienable right. ${ }^{100}$

Similarly, Lyman Trumbull, the influential moderate Republican Senator from Illinois, also noted the inconsistency between the Declaration, which proclaimed the equal rights of all to life, liberty, and happiness, and the denial of liberty, happiness, and life itself to a whole race..$^{101}$

Debates on the Thirteenth Amendment also contain other direct appeals to higher law. One outspoken member of the House, for example, favored the Thirteenth Amendment because it would "secure to the oppressed slave his natural and God-given rights." Among those inalienable rights, the Representative said, were the right to live, to enjoy the fruit of his own labor, and the "right to the endearments and enjoyment of family ties." 102 When they sought to protect basic rights in the Fourteenth Amendment such as freedom of speech, the same legislators were keenly aware that those rights were not necessarily the consensus

99. U.S. CONST. amend. VII:

In Suits at common Iaw, where the value in controversy shall exceed twenty dollars, the right of trial by jury shall be preserved, and no fact tried by a jury, shall be otherwise re-examined in any Court of the United States, than according to the rules of the common law.

100. Cong. Globe, 38th Cong., Ist Sess. 1313 (I864). Other references to the Declaration can be found in Sen. Henderson's remarks, id. at 1461; in Sen. Sumner's remarks, id. at 1482B83; and in Rep. Orth's remarks, id., 38th Cong., 2d Sess. 142 (1865). In the 1864 enabling acts for Colorado, Nevada, and Nebraska, Congress required them to follow the Declaration of Independence.

10I. Cong. Globe, 38th Cong., Ist Sess. 1313, 1424 (1864).

102. Id. at 2990 . 
norms of American society: they had often been violated in Southern states and sometimes in the North. ${ }^{103}$

In understanding the Reconstruction Republicans, it is important to keep in mind that they viewed the Declaration of Independence as being the foundation of American identity, at least as much as the Constitution. It was for this reason that Lincoln's Gettysburg address refers to the founding of the nation "four score and seven years ago"-a reference to 1776 , not I789. Lincoln's election platform demanded "the maintenance of the principles promulgated in the Declaration of Independence and embodied in the Federal Constitution" such as equality and inalienable rights. ${ }^{104}$ Lincoln himself spoke fervently and often about the Declaration. ${ }^{105}$ There is no question that the authority of "We the People" played a significant role in establishing the Constitution, but there is also no question that a universalistic vision of inalienable rights also permeates our constitutionalism.

Earlier, during the Bill of Rights period, judicial opinions, state constitutional provisions, and pronouncements by statesmen made it clear that rights stemmed from a greater source than any local charter or constitution. The Declaration of Independence embodied this universalistic view: it said that men were endowed by their creator with certain inalienable rights; it didn't say "as Britons, we are endowed by English common law and statute with certain rights." Of course, the colonists thought the second part was true too, and they thought to a large extent the rights of Englishmen were a practical codification of the rights of mankind. ${ }^{106}$ But at a deep level of principle, they thought rights were not merely creatures of local law.

A least one snippet of constitutional text also bears on the question of constitutional nationalism versus internationalism. The Bill of Rights, by and large, simply presents rights without explaining the reasons. However, there is one exception-the Second Amendment. Recall the text of the Amendment: "A well-ordered militia, being necessary to the security of a free State, the right of the people to keep and bear Arms, shall not be abridged." This is the one place where the Constitution explains its own rationale for protecting a specific right.

This rationale for protecting the right to bear arms is something that not everyone would agree with today, but what is clear is that Second Amendment does not purport to be based on any peculiarly American principle. The Second Amendment could have said, "a well-ordered militia being necessary to our national security," or "a well-ordered militia being a

103. See FARBER \& SHERRY, supra note 37 , at 381-82.

104. Id. at 378 .

105. Id. at $377-79$.

106. See FARBER \& SHERRY, supra note 37 , at 8-15. 
fundamental principle of American government." Instead, the amendment claims to derive from a universal truth about what is necessary for a free society. I do not want to get into the thicket of the gun control debate here. The point I make is simply that, the one time the Framers chose to speak about their reason for protecting rights in the Constitution itself, they invoked what they considered to be a universal principle rather than anything specific to America. It seems unlikely that they took the militia to be a universal, but considered freedom of speech and religion or the unacceptability of cruel and unusual punishments to be merely local conceptions. The theory surely was not just that "cruel and unusual punishments are outside our local norms" or "cruel and unusual punishment is something we have decided to ban as an act of popular sovereignty."

To the extent that constitutional provisions embody universalistic concerns, then, there is every reason to consider how those concerns have been understood elsewhere in the world. If religious freedom is a universal concept, for example, we can gain insights from considering how other thinkers outside of our own country have understood it, although in the end we may decide that the specific features of the U.S. Constitution call for a different solution. ${ }^{107}$

The common sense of the matter is explained by Jeremy Waldron. ${ }^{108}$ He asks us to consider how we would expect our public health authorities to respond to a new disease threat. "It would be ridiculous to say that because this problem had arisen in the United States, we should look only to American science to solve it." ${ }^{, 109}$ On the contrary, he observes, we would try to learn as much as we could from the work of scientists around the world. The same, he says, is true for tough constitutional problems such as the scope of the concept of "cruel and unusual punishment," as applied to questions such as the execution of juveniles. ${ }^{110}$ These are difficult issues, not easy to think through. By seeing what jurists in other parts of the world have to say, we join in "the enterprise, which many legal systems share, of grappling with, untangling, and resolving the rival rights and claims that come together in issues of this kind."111

This is certainly not controversial in other areas of the law. For example, the law of torts even today is largely based on judicial decisions

107. In particular, given that our Constitution prohibits religious establishments, thc experience of countries such as Israel and Britain may not be relevant; on the other hand, unlike the resolutely secular vision adopted by the French, our Constitution also privileges religious practice through the Free Exercise clause.

108. Jeremy Waldron, Foreign Law and the Modern Ius Gentium, 119 HARv. L. REv. 129 (2005).

109. Id. at 143.

110. Id. at 140.

111. Id. 
rather than statutes. There are many tough issues in tort law, for example, about when an accident is so unforeseeable that the defendant should not be held responsible. ${ }^{12}$ Some of the leading cases that deal with this issue are English. ${ }^{113}$ It would be peculiar for a modern American judge to write off the reasoning of these cases as un-American and therefore as unworthy of serious consideration, or for anyone to call for legislation banning the citation of torts decisions from other jurisdictions.

\section{$\mathrm{V}$}

\section{How to USE Foreign Law}

If history and tradition count for anything, it is entirely appropriate for the Supreme Court to consider relevant foreign materials when interpreting the U.S. Constitution, particularly those provisions that embody universalistic aspirations. This is not to say, however, that the use of foreign legal materials is completely unproblematic. Those materials need to be used with care. Judges are mevitably going to be more at home with domestic sources of law. Clearly, the less familiar the foreign Iegal system, the more trouble American judges might have in assessing the significance of particular doctrines. ${ }^{114}$ Countries like Canada that share much of our legal tradition will be the easiest to assess. Thus, judges may want to be selective in terms of which foreign materials to consider, focusing on other legal systems that do not present severe interpretative difficulties. These considerations counsel caution in our use of foreign authority, not a reason to ignore out of hand the potentially usefuI insights of other legal systems.

It's true that using foreign authority takes judges outside of their area of greatest familiarity, but this is also true of using historical evidence (as originalists demand). For that matter, courts routinely use economics in antitrust cases, which is at least as far outside their core expertise as interpreting Canadian or German constitutional decisions.

Allied to the difficulty of assessing foreign materials is the need to determine how much weight to give them. ${ }^{115}$ Essentially, the closer a

112. Palsgraf v. Long Island R.R. Co., 248 N.Y. 339 (1928).

113. See, e.g., In re Polemis, [1921] 3 K.B. 560 (Ct. App. 1921); Overseas Tankship (U.K.) Ltd. V. Morts Dock \& Engineering Co., Ltd. (The Wagon Mound), [1961] A.C. 388; Smith v. Leech Brain \& Co., [1962] 2 Q.B. 405; and Blyth v. Birmingham Waterworks Co., 11 Exch. 781 (1856).

114. For example, it is obviously important to understand a foreign court's composition, procedural rules, and jurisdiction in order to understand the import of specific decisions. See Robert J. Krotoszynski, Jr., "I'd Like to Teach the World to Sing (in Perfect Harmony)": International Judicial Dialogue and the Muses - Reflections on the Perils and the Promise of International Judicial Dialogue, 104 Mich. L. REv. 1339-4I (2006).

115. I do not agree, however, that the Court needs a precise headcount in order to factor foreign decisions into a precise formula, any more than common law courts necessarily need such a headcount in order to consider the rulings of other common law jurisdictions. For the contrary view, see Ernest A. Young, Foreign Law and the Denominator Problem, 199 HARv. L. Rev. 148 (2005). In fairness to Professor Young, it should be said that some of the Court's applications of foreign law, particularly in the Eighth Amendment context, may invite this interpretation. This seems to be part and parcel of the 
foreign jurisdiction is to the U.S. in terms of historical connections, constitutional provisions, and legal institutions, the more relevant that jurisdiction's decisions. ${ }^{116}$ Foreign law is also entitled to more weight when it is persuasively justified; and to less weight when it seems to reflect another country's peculiarities. For example, some countries have a single dominant religion which is tightly integrated into their political and legal systems. To the extent that legal rulings rest on the sectarian views of such a religion, they are less relevant to our more pluralistic society, especially given our constitutional prohibition on the establishment of religion. For this reason, the almost total ban on abortions in Ireland at the behest of the Catholic Church may not tell us very much one way or the other about how we should interpret our own constitution. ${ }^{117}$

The practical problems of making use of foreign authority should not be dismissed. Those problems can be rendered more manageable, however, by identifying specific jurisdictions whose rulings are most likely to be relevant and specific legal issues where recourse to legal authority is most likely to be helpful. In terms of specific jurisdictions, U.S. courts might do well to begin by focusing on the Canadian Supreme Court and key European courts (ECHR and European Court of Justice). Considering the rulings of these courts is appealing for several reasons. Europe and Canada are like the United States in being well-established modern democracies with advanced economies. The European and Canadian courts are like the American federal courts, in that they preside over "federal" systems whose members have diverse values and political dynamics. Last but not least, their decisions are readily available in English. Somewhat less central, but also worth considering on occasion, are the decisions of the German Constitutional Court, particularly since Americans had such a large role in shaping the German Basic Law. Another court whose views may be particularly useful is the Israeli Supreme Court, which works within a common-law tradition with important Anglo-American influences and which also has vast experience with the terrorism issues that confront our legal system today.

In terms of specific subject areas where international precedent might be helpful, three issues might provide good starting points for our courts. First, as Justice Kennedy's opinion in Lawrence suggests, international rulings may be helpful when our courts try to determine whether a particular right is fundamental enough to enjoy constitutional protection. Whether a right is recognized as fundamental in other democracies can

Court's general approach to the Eighth Amendment, which uses a census of jurisdictions to determine whether a punishment is "unusual." See Roper v. Simmons, 125 S. Ct. 1183 (2005).

116. For a discussion of the utility and limits of comparative constitutionalism, see Jackson, supra note 98 .

117. As Professor Jackson says, "[c]onsidering the questions other systems pose may sharpen understanding of how we are different." Jackson, supra note 98, at 117. 
provide an important signal of how it should be regarded within U.S. law, although foreign rulings are obviously not controlling. ${ }^{18}$

Second, in the controversial area of civil liberties and anti-terrorism measures, our legal system has only begun to struggle with these issues over the past decade. Other democracies have longer histories. Our courts can get a better sense of what incursions on civil liberties should be considered necessary to achieve a compelling governmental interest by considering the European experience. Besides the decisions of the ECHR, it may also be worth considering decisions at the national level from the United Kingdom, Israel, and Germany, which have faced serious terrorism issues for several decades. In some cases, the lessons from these other legal systems may be negative, if we determine that they allowed restrictions on civil liberties that were unnecessary or intolerable in our own society. In other cases, their experience will provide some support for the actions of our own government.

Finally, to take a much less dramatic issue, the dormant commerce clause doctrine requires the Supreme Court to determine when state legislation infringes on the right of free trade within the United States. The European Court of Justice faces similar problems, and its jurisprudence may be instructive. Rulings by the World Trade Organization may also be helpful for similar reasons. All of these tribunals face similar problems in balancing a commitment to free trade with the prerogatives of local regulators.

The experience of other legal systems may also be instructive about the appropriate role of courts. When deciding whether to recognize a right, judges often consider whether the right can be given a reasonably clear definition and whether the judiciary is in a position to provide an effective remedy. Looking at foreign experience can be helpful in addressing both those concerns. The result is not necessarily to reinforce an argument for expanding constitutional rights; on the contrary, examining foreign experience can reaffirm concerns about the workability or desirability of recognizing additional rights.

For example, the U.S. Supreme Court has withdrawn almost entirely from reviewing constitutional issues relating to economic regulation. In the Lochner era, it reviewed such regulations intensively to determine if they were reasonable. Since 1937, the Court has simply dropped out of this enterprise completely. ${ }^{119}$ One reason has been a fear that there is no principled way to distinguish between valid and invalid regulations,

118. This analysis is applied to a wide range of legal issues, from abortion to gay marriage to educational rights, in FARBER, supra note $\uparrow$.

119. Erwin Chemerinsky, Constitutional Law: Principles and Policies 601-605 (2d ed. 2002); see generally Ronald D. Rotunda \& John E NowaK, TREatise on Constitutional Law: Substance \& Procedure 438-60 (3d ed. 1999). 
making the decisions inherently political. In this regard, rather than simply assuming that the problem of line-drawing is unsolvable, it is instructive to look at foreign decisions that have tried to draw such lines.

An illuminating example is provided by the German Basic Law, which recognizes a right of occupational freedom, giving all Germans the right to freely choose their occupation. ${ }^{120}$ This is a somewhat appealing notion because the right to choose a career can be critical to the ability to lead an autonomous life. But before considering whether to embrace this right, it would be helpful to know more about the German experience. Have the Germans managed to define the boundary of this right in a principled way? Has the right played a useful role in German law? Has it left reasonable space for government regulation? The answers to these questions obviously do not dictate whether this right should be considered part of our own constitutional order, but they do help address some relevant concerns.

In this instance, the German experience is not encouraging about whether a right to employment can be defined in a discrete form that protects fundamental personal interests rather than simply allowing courts to second-guess economic legislation. It is ground for concern that the German courts have extended constitutional protection to the right to make chocolate-covered puffed rice. ${ }^{21}$ The legislature banned the sale of products that might be confused with chocolate candies; the courts thought a simple warning would be good enough. The question of how best to eliminate consumer confusion does not involve any specifically judicial expertise, and it is hard to see a fundamental human right at stake in the Chocolate Candy Case. Of course, deeper research into the law of Germany and other countries might help assuage some of these concerns. (Or maybe not, if a 1990 summary of the German cases provides a fair picture of the law today.) $)^{122}$ Still, even without in-depth examination of foreign law, the German chocolate candy case does seem to provide some support for our own Supreme Court's reluctance to get involved in these disputes. Those who view foreign jurisprudence as merely providing an excuse for activism fail to recognize that it may also provide a basis for judicial restraint.

\section{CONCLUSION}

Whatever you think of the arguments pro and con about foreign law, one thing is clear. Citing foreign law is an American tradition that goes

120. Grundgesetz für die Bundesrepublik Deutschland [GG] [Basic Law] May 23, 1949, as amended, Ch. 1, art. 12 .

121. Chocolate Candy Case, 53 BVerfGE 135 (1980).

122. David P. Currie, Lochner Abroad: Substantive Due Process and Equal Protection in the Federal Republic of Germany, 1989 SUP. CT. REV. 333 (1990). 
back to the first days of the Republic. It is the ones who want to end this practice who are the radicaIs here - providing perhaps another confirmation of Cass Sunstein's description of some conservative activist judges as "radicals in black robes.",

It is important to be clear on what is at stake here. I am not saying and as far as I know, nobody else is saying - that foreign law is binding on the Supreme Court's interpretation of the Constitution. What I am saying is that foreign law often addresses the same fundamental issues that arise under our Constitution. This is particularly true of provisions that were founded in universalistic concerns rather than on the nature of our federal system or our doctrine of separation of powers. Ignoring potential sources of wisdom about universal concerns, simply because the authors lack American passports, is misguided.

The point is simply that these tribunals grapple with similar problems, so their rulings may have something to teach our courts. Just as common law courts look beyond their own borders when faced with difficult issues of tort or contract law, so the federal courts should do so in the constitutional realm. When other able people struggle earnestly with the same issues that concern us, it seems foolish to me to ignore their efforts. Or, if I am wrong about this, at least I have the comfort of being in good company, joined by many of the Founding generation and the framers of the Reconstruction Amendments, along with Supreme Court Justices stretching back to John Marshall. ${ }^{124}$

Admittedly, we have much to learn about the relevant foreign legal systems. We also have much thinking to do about the import of their rulings for our own constitutional system. As we confront these issues as a profession, we may do well to remember the example of great teachers and scholars such as Paul Mishkin. Just as the great issue a generation ago was to elaborate on the role of the federal courts in the federal system, so the emerging issue today is the role of the federal courts in the international system. The issues we face may be different, but the need for deep learning, rigorous thinking, and dedication to the life of the law remains the same.

123. Cass R. Sunstein, Radicals in Robes: Why Extreme Right-wing Courts are Wrong For AMERICA (2005).

124. The example of the Founding generation is also heartening in that it shows how American lawyers are quite capable of acquiring a working knowlcdge of international legal authorities. If Adams, Hamilton, and many lesser-known lawyers eould master the law of nations even without the benefit of a law school education, so can today's law students and lawyers. 
